\title{
Amenorea Sekunder: Tinjauan dan Diagnosis
}

\author{
Erna Suparman, Eddy Suparman
}

Bagian/SMF Obstetri dan Ginekologi Fakultas Kedokteran Universitas Sam Ratulangi/ RSUP Prof. Dr. R. D. Kandou Manado

Email: ernasuparman@yahoo.com

\begin{abstract}
Secondary amenorrhea occurs when a woman in reproductive age who has experienced menstruation, at a sudden stops menstruating for at least three consecutive months. The basic principle underlying the physiology of menstrual function is composed of multiple organ systems with their appropriate compartments in which the menstrual cycle depends on, as follows: compartment I, disorders of the uterus; compartment II, disorders of the ovary; compartment III, disorders of the anterior pituitary; and compartment IV, disorders of the central nervous system (hypothalamus). Finding the cause of secondary amenorrhoea can be done by doing some tests or trials. Determination of the location of the specific anatomical defect is useful to obtain appropriate treatment according to the cause of amenorrhea.
\end{abstract}

Keywords: secondary amenorrhoea

\begin{abstract}
Abstrak: Dikatakan amenorea sekunder bila seorang wanita usia reproduktif yang pernah mengalami haid, tiba-tiba haidnya berhenti untuk sedikitnya 3 bulan berturut-turut. Prinsip dasar yang mendasari fisiologi dari fungsi menstruasi memungkinkan penyusunan beberapa sistem kompartemen yang tepat di mana siklus menstruasi bergantung, yaitu: kompartemen I gangguan pada uterus, kompartemen II gangguan pada ovarium, kompartemen III gangguan pada hipofisis anterior, dan kompartemen IV gangguan pada sistem saraf pusat (hipotalamus). Gangguan ini sering berhubungan dengan keadaan stres (wanita pengungsi, dipenjara, hidup dalam ketakutan), atlit wanita, atau anoreksia nervosa dan bulimia. Mencari penyebab amenorea dapat diperoleh dengan melakukan beberapa uji atau percobaan. Penentuan lokasi defek anatomis spesifik sangat bermanfaat untuk mendapatkan penanganan yang sesuai dengan penyebab amenore.
\end{abstract}

Kata kunci: amenorea sekunder

Dikatakan amenorea sekunder bila seorang wanita usia reproduktif yang pernah mengalami haid, tiba-tiba haidnya berhenti untuk sedikitnya tiga bulan berturut-turut. Penyebab tidak datangnya haid ialah gangguan pada organ-organ yang bertanggung jawab terhadap proses terjadinya siklus haid, yaitu: hipotalamushipofisis (amenorea sentral), ovarium (amenorea ovarium), dan uterus (amenorea uteriner). Pervalensi amenorea sekunder sekitar 3-4\% wanita usia reproduktif, sebagian besar kasus disebabkan oleh sindroma ovarium polikistik (SOPK), amenorea hipotalamik, hiperprolaktinemia, dan kegagalan ovarium dini. ${ }^{1}$

Prinsip dasar fisiologi dari fungsi menstruasi memungkinkan penyusunan beberapa sistem kompartemen yang tepat di mana siklus menstruasi bergantung. Prinsip ini berguna untuk mendapatkan evaluasi diagnostik yang memisahkan penyebab dari amenore ke dalam kompartemen berikut ini: kompartemen I, gangguan pada uterus; kompartemen II, gangguan pada ovarium; kompartemen III, gangguan pada hipofisis 
anterior; dan kompartemen IV, gangguan pada sistem saraf pusat (hipotalamus). ${ }^{3}$

\section{Kompartemen gangguan haid}

Kompartemen I: Gangguan pada uterus Sindrom Asherman

Pada sindrom Asherman, amenore sekunder terjadi setelah kerusakan endometrium. Umumnya hal ini disebabkan kuretase berlebihan yang kemudian menghasilkan jaringan parut intrauterin. Pola yang khas yaitu sinekia multipel yang tampak pada histerogram. Diagnosis dengan histeroskopi lebih akurat karena dapat mendeteksi perlekatan minimal yang tidak tampak pada histerogram. Perlekatan dapat terjadi secara sebagian atau seluruhnya menutup rongga endometrium atau kanalis servikalis. Sindrom Asherman dapat juga terjadi setelah pembedahan uterus, meliputi seksio saesaria atau miomektomi. ${ }^{3}$

Pasien dengan sindrom Asherman dapat memiliki masalah lain selain amenore, termasuk keguguran dan dismenore. Pasien dengan abortus berulang, infertilitas, atau kegagalan kehamilan harus menjalani pemeriksaan rongga endometrium dengan histerogram atau histeroskopi. ${ }^{3}$

Terapi sindrom Asherman meliputi dilatasi dan kuretase untuk melepaskan sinekia dan bila diperlukan dapat dilakukan histerogram untuk memastikan rongga uterus telah bebas dari sinekia. Histeroskopi dengan melisiskan secara langsung perlekatan, memberikan hasil yang lebih baik daripada dilatasi dan kuretase "buta". Untuk mencegah rongga uterus dari perlekatan digunakan kateter Folley intra uterin, kantung diisi dengan $3 \mathrm{ml}$ cairan, dan kateter diangkat setelah 7 hari. Selain kateter Folley, intrauterine device (IUD) juga dapat digunakan untuk mencegah perlekatan ulang. Kateter Folley merupakan metode ajuvan yang lebih aman dan lebih efektif dibandingkan dengan IUD. Hal ini didukung oleh penelitian yang dilakukan Orhue et al. yang membandingkan 51 kasus sindrom Asherman yang menggunakan IUD dan 59 kasus dengan kateter Folley untuk mencegah perlekatan ulang dan ditemukan $81,4 \%$ pasien dari kelompok kateter Folley mendapatkan siklus menstruasi yang normal sedangkan pada kelompok IUD sebanyak 62,7\%. Tingkat konsepsi pada kelompok kateter ialah $33,9 \%$ dibandingkan dengan $22,5 \%$ pada kelompok IUD. Antibiotik spektrum luas dimulai sebelum operasi dan dipertahankan selama 10 hari. Pasien diterapi selama 2 bulan dengan estrogen dosis tinggi $2,5 \mathrm{mg}$ perhari selama 3 dari 4 minggu dan dengan medroksi-progesteron asetat $10 \mathrm{mg}$ perhari yang ditambahkan pada minggu ketiga. ${ }^{3-5}$

\section{Kompartemen II: Gangguan pada ovarium}

Tumor ovarium

Amenorea yang terjadi dapat disebabkan oleh tumor ovarium yang tidak memroduksi hormon maupun oleh tumor ovarium yang memroduksi hormon. Tumor ovarium yang tidak memroduksi hormon akan merusak seluruh jaringan ovarium. Hormon yang diproduksi oleh tumor ovarium ialah androgen dan estrogen. Androgen yang tinggi menekan sekresi gonadotropin, sehingga menyebabkan amenorea, hirsutisme, hipertrofi klitoris, perubahan suara, dan akne. Tumor yang memroduksi estrogen jarang menyebabkan amenorea, namun sering terjadi perdarahan yang memanjang akibat hiperplasia endometrium. ${ }^{2}$

Kegagalan ovarium dini/premature ovarian failure (POF)

Sekitar $1 \%$ wanita akan mengalami kegagalan ovarium dini (deplesi dini dari folikel ovarium) sebelum usia 40 tahun. Etiologi dari kegagalan ovarium dini pada sebagian besar kasus belum diketahui dan lebih sering terjadi pada keluarga yang memiliki sindrom $\mathrm{X}$ fragil; hal ini berguna bila kegagalan ovarium dini familial diidentifikasi. Perlu ditekankan bahwa pembawa mutasi $\mathrm{X}$ fragil ialah pada peningkatan risiko untuk kegagalan ovarium dini. Gangguan autosomal dominan yaitu sindrom blefaro-fimosis (kelainan kelopak mata), telah diidentifikasi berhubungan dengan kegagalan 
ovarium dini, yang disebabkan oeh mutasi dalam gen faktor transkripsi (FOXL2) pada kromosom 3. Selain itu, kegagalan ovarium dini dapat disebabkan oleh destruksi folikel karena infeksi, misalnya ooforitis gondok, atau kerusakan fisik (misalnya radiasi atau kemoterapi). ${ }^{3,6}$

Efek radiasi tergantung pada usia dan dosis sinar $\mathrm{X}$. Kadar estrogen dan progesteron mulai menurun dan gonadotropin meningkat dalam 2 minggu setelah radiasi ovarium. Pada wanita berusia lebih muda yang terpapar dengan radiasi kuat akan lebih sulit terjadi efek kastrasi total, karena memiliki jumlah oosit yang lebih banyak. Kerusakan ovarium mungkin tidak terjadi saat itu, namun akan muncul di kemudian hari dalam bentuk kegagalan ovarium dini. Bila daerah radiasi di luar pelvis, tidak terdapat risiko kegagalan ovarium dini. Untuk alasan ini, transposisi elektif ovarium menggunakan laparoskopi dari ovarium di luar pelvis sebelum radiasi memberikan harapan yang baik untuk fungsi fertilitas di masa akan datang. ${ }^{3}$

Tabel 1. Risiko infertilitas menurut dosis ${ }^{3}$

\begin{tabular}{cc}
\hline Dosis ovarium & Efek infertilitas \\
\hline $60 \mathrm{rad}$ & Tidak ada efek \\
$150 \mathrm{rad}$ & Beberapa risiko di atas \\
& usia 40 tahun \\
$250-500 \mathrm{rad}$ & Usia 15-40 tahun: \\
& $60 \%$ infertil \\
$500-800 \mathrm{rad}$ & Usia 15-40 tahun: \\
& $60-70 \%$ infertil \\
Di atas $800 \mathrm{rad}$ & $100 \%$ infertil permanen \\
\hline
\end{tabular}

Sindrom resistensi ovarium

Sindrom resistensi ovarium terjadi pada wanita amenore dengan pertumbuhan dan perkembangan yang normal, namun memiliki peningkatan kadar gonadotropin. Wanita ini akan sulit untuk hamil, bahkan dengan dosis gonadotropin eksogen yang tinggi. Penyebab pasti kelainan ini belum sepenuhnya terungkap. Diduga adanya gangguan pembentukan reseptor gonadotropin di ovarium akibat proses autoimun. Perlu dilakukan biopsi ovarium untuk membedakan dengan menopause prekok. ${ }^{2,3}$

\section{Sindroma ovarium polikistik (SOPK)}

Sindrom ovarium polikistik adalah suatu anovulasi kronik yang menyebabkan infertilitas dan bersifat hiperandrogenik, di mana terjadi gangguan hubungan umpan balik antara pusat (hipotalamus-hipofisis) dan ovarium sehingga kadar estrogen selalu tinggi yang berakibat tidak pernah terjadi kenaikan kadar FSH yang cukup adekuat. ${ }^{7}$

Gambaran klinis SOPK sangat bervariasi, tetapi secara umum dapat dijumpai gangguan menstruasi dan gejala hiperandrogenisme. Keadaan klinis yang ditemukan ialah gangguan menstruasi dengan siklus menstruasi tidak teratur atau tidak menstruasi sama sekali, terkadang disertai terjadinya perdarahan uterus disfungsional. Gejala hiperandrogenisme berupa hirsutisme, kelainan seboroik pada kulit dan rambut serta kebotakan dengan pola seperti yang ditemukan pada pria. Tes laboratorium yang dilakukan berupa tes hormonal, tidak saja penting untuk diagnosis tetapi juga sangat penting untuk melihat kelainan secara keseluruhan. Kelainan endokrin yang ditemukan ialah peningkatan konsentrasi LH dan aktivitas androgen yaitu testosteron dan androstenedion. Pada pemeriksaan ultrasonografi transvaginal didapatkan gambaran lebih dari 10 kista pada salah satu ovarium dengan ukuran $<1 \mathrm{~cm}^{8}{ }^{8}$

\section{Kompartemen III: Gangguan pada hipofisis anterior \\ Sindrom Sheehan}

Penyebab terbanyak amenorea karena gangguan di hipofisis ialah sindrom Sheehan yang terjadi akibat adanya iskemik atau nekrosis adenohipofisis. Kelainan ini sering dijumpai pada postpartum dengan perdarahan banyak. Perlu diketahui, bahwa adenohipofisis sangat sensitif dalam kehamilan. Gejala baru muncul bila $3 / 4$ dari adenohipofisis mengalami kerusakan. Bila hal ini terjadi, maka semua hormon yang dihasilkan oleh adenohipofisis akan mengalami gangguan. ${ }^{2,9}$

\section{Amenorea galaktorea}

Pada wanita dengan oligomenore, 
amenore, galaktorea atau infertilitas, harus diperiksa kadar prolaktin serum. Hiperprolaktinemia diperkirakan terjadi pada $9 \%$ wanita dengan amenore, 25\% wanita dengan galaktorea, dan $70 \%$ wanita dengan amenore dan galaktorea. Prolaktin merupakan hormon yang diproduksi oleh sel-sel laktotrof yang terletak di bagian distal lobus anterior hipofisis. Pengeluaran prolaktin dihambat oleh prolactin inhibiting factor (PIF) yang identik dengan dopamin. Bila PIF ini tidak berfungsi, atau produksinya berkurang maka akan terjadi hiperprolaktinemia. Tidak berfungsinya PIF dapat disebabkan oleh: gangguan di hipotalamus; obat-obatan (psikofarmaka, estrogen, domperidon, simetidin); kerusakan pada sistem portal hipofisis; dan tumor hipofisis yang menghasilkan prolaktin (prolaktinoma), hipertiroid, dan akromegali. $3,10,11$

Hiperprolaktinemia mengakibatkan reaksi umpan balik terhadap hipotalamus, sehingga terbentuk dopamin dalam jumlah besar yang akan menghambat pengeluaran gonadotropin-releasing hormone ( $\mathrm{GnRH})$ dan dengan sendirinya akan terjadi penurunan sekresi FSH dan LH. Hiperprolaktinemia juga menyebabkan penurunan sensitivitas ovarium terhadap FSH dan LH, memicu produksi asi, serta memicu sintesis androgen suprarenal. ${ }^{2}$

Pada hiperprolaktinemia didapatkan kadar prolaktin yang tinggi di dalam darah (normal 5-25 ng/ml). Bila didapatkan kadar prolaktin yang tinggi harus dicari ada tidaknya prolaktinoma dengan menggunakan MRI atau CT scan. Umumnya terjadi gangguan haid mulai dari oligomenorea sampai amenorea yang sangat bergantung dari kadar prolaktin serum. Kadar prolaktin $>100 \mathrm{ng} / \mathrm{ml}$ selalu menyebabkan amenorea. Hiperprolaktinemia mengakibatkan timbulnya gangguan pada pertumbuhan folikel, sehingga ovulasi tidak terjadi. Kadangkadang pasien mengeluh sakit kepala yang disertai dengan amenorea, serta gangguan penglihatan. Bila hal ini ditemukan maka harus dipikirkan adanya prolaktinoma. ${ }^{2}$ Kompartemen IV: Gangguan pada sistem
saraf pusat

Amenore hipotalamik

Gangguan hipotalamus didiagnosis dengan menyingkirkan lesi hipofisis. Gangguan ini sering berhubungan dengan keadaan yang penuh dengan tekanan. Penyebab fungsional yang paling sering ditemukan berupa gangguan psikis. Gangguan fungsional seperti ini paling banyak dijumpai pada wanita pengungsi, dipenjara, sering mengalami stres, atau hidup dalam ketakutan. Pasien dengn amenore hipotalamik (hipogonadotropin hipogonadisme) memiliki defisiensi dari sekresi pulsatil GnRH. Tingkat penekanan GnRH menentukan bagaimana klinis pasien ini. Penekanan ringan dapat berhubungan dengan efek marginal dari reprofuksi, khususnya fase luteal yang tidak adekuat. Penekanan sedang dapat menghasilkan anovulasi dengan ketidakteraturan menstruasi, dan penekanan yang kuat bermanifestasi sebagai amenore hipotalamik. ${ }^{2,3}$

\section{Anoreksia nervosa dan bulimia}

Wanita yang mengalami gangguan pola makan seperti anoreksia nervosa dan bulimia dapat menyebabkan gangguan psikis, dan neurotik, sehingga dapat terjadi kerusakan organ (atrofi). Bila kerusakan tersebut mengenai hipotalamus, maka dengan sendirinya hipotalamus tidak dapat lagi memroduksi GnRH. Pengeluaran FSH dan LH dari hipofisis pun berhenti. Akibatmya pematangan folikel dan ovulasi di ovarium tidak terjadi. Anoreksia nervosa diagnosis bila ditemukan gejala berikut: ${ }^{2,3}$

1. Onset antara usia 10 dan 30 tahun.

2. Penurunan berat badan sebanyak $25 \%$ atau $15 \%$ di bawah normal untuk usia dan tinggi badan.

3. Kelakuan khusus: penyangkalan, gambar tubuh yang berubah, perlakuan yang tidak biasa terhadap makanan.

4. Sedikitnya satu dari berikut ini: rambut halus (lanugo), bradikardi, overaktivitas, episode makan berlebihan (bulimia), muntah, yang dapat diinduksi oleh diri sendiri. 
5. Amenore.

6. Tidak ada penyakit medis yang diketahui.

7. Tidak ada kelainan psikiatrik lain

Bulimia merupakan sebuah sindrom yang ditandai dengan makan berlebihan yang episodik dan diikuti dengan induksi muntah, puasa, dan penggunaan laksatif dan diuretik, bahkan enema. Tampaknya ini merupakan permasalahan yang berkembang pada wanita muda. Perilaku bulimik sering tampak pada pasien dengan anoreksia nervosa. Pasien dengan bulimia memiliki insidensi gejala depresif yang tinggi atau gangguan kecemasan. Baik anoreksia nervosa maupun bulimia menetap sebagai masalah kronis yang berjangka waktu lama yang ditemukan pada $50 \%$ kasus. $^{12}$

\section{Olah raga dan amenore}

Atlet wanita dengan olahraga yang penuh tekanan memiliki peningkatan insidensi bermakna dari ketidakteraturan menstruasi dan amenore akibat efek penekanan hipotalamus. Bila latihan dimulai sebelum menarke, menarke dapat tertunda hingga 2-3 tahun, dan insidensi berikutnya dari ketidakteraturan menstruasi lebih tinggi. Olahraga menurunkan gonadotropin dan meningkatkan prolaktin, hormon pertumbuhan, testosteron, ACTH, steroid adrenal, dan endorfin sebagai akibat dari sekresi yang meningkat maupun bersihan yang berkurang. ${ }^{3,13}$

Hormon yang melepaskan kortikotropin $(\mathrm{CRH})$ secara langsung menghambat sekresi GnRH hipotalamik, mungkin dengan meningkatkan sekresi opioid endogen. Wanita dengan amenore hipotalamik (termasuk olahragawan dan wanita dengan gangguan pola makan) memperlihatkan hiperkortisolisme (karena peningkatan CRH dan ACTH), yang menunjukkan bahwa ini merupakan jalur dimana tekanan mengganggu fungsi reproduktif. Atlet amenore yang memiliki kadar kortisol kembali ke rentang normal memperoleh kembali fungsi menstrual dalam 6 bulan, kebalikan dengan atlet yang mempertahankan kadar kortisol yang meningkat dan terus mengalami amenore. ${ }^{14}$
Terdapat beberapa perbedaan penting antara reaksi anorektik dan anoreksia nervosa sejati. Pasien dengan anoreksia nervosa sejati memiliki persepsi yang salah tentang realitas dan kurang kesadaran diri terhadap penyakit dan masalahnya sedangkan pasien dengan reaksi anorektik memiliki kemampuan untuk menilai diri sendiri. Atlet wanita yang bertanding dapat mengalami reaksi anorektik mereka dengan sengaja berusaha untuk mengurangi berat badan. Seorang dokter harus waspada akan masalah ini dan akan ditemui oleh pasien karena keluhan yang terjadi baik amenore maupun penurunan berat badan yang tidak terkontrol lagi. ${ }^{3,15,16}$

\section{Beberapa uji untuk mencari penyebab amenorea}

Uji dengan menggunakan progestogen, (uji P)

Bila ternyata wanita tersebut diyakini tidak hamil, maka baru boleh dilakukan uji P. Jenis-jenis progestogen yang dapat digunakan ialah medroksiprogesteron asetat (MPA), noretisteron, didrogesteron, atau nomegestrol asetat. Dosis progestogen untuk uji $\mathrm{P}$ ialah 5-10 mg/hari dengan lama pemberian 7 hari. Umumnya perdarahan akan terjadi 3-4 hari setelah obat habis, dan dikatakan uji $\mathrm{P}$ pada wanita ini positif. Jika dalam 10 hari setelah obat habis belum juga terjadi perdarahan, maka dikatakan uji $\mathrm{P}$ negatif. ${ }^{2}$ Bila terjadi perdarahan setelah uji $\mathrm{P}$, berarti wanita tersebut masih memiliki uterus, dengan endometrium normal. Perdarahan dapat keluar dari alat genitalia wanita tersebut, berarti wanita tersebut memiliki vagina dan himen yang normal. Perdarahan dapat terjadi karena endometrium telah mendapat pengaruh estrogen yang cukup (proliferasi). Estrogen dihasilkan oleh ovarium, tepatnya di folikel, artinya wanita tersebut memiliki ovarium dan pertumbuhan folikel yang normal. Folikel-folikel di ovarium baru dapat menghasilkan estrogen bila sebelumnya telah mendapat rangsangan dari $\mathrm{FSH}$ dan LH. Karena FSH dan LH disintesis di hipofisis dan pengeluarannya dipicu oleh hormon pelepas GnRH, maka dapat 
dikatakan bahwa wanita tersebut memiliki hipofisis dan hipotalamus yang normal. Pemberian progesteron pada wanita ini menyebabkan endometrium menjadi fase sekresi, dan begitu kadar progesteron turun terjadilah perdarahan. Dapat dikatakan bahwa wanita ini kekurangan progesteron yang dihasilkan oleh korpus luteum. Korpus luteum baru akan terbentuk bila pada seorang wanita terjadi ovulasi. Jadi pada wanita ini kemungkinan tidak terjadi ovulasi. Pada analisis hormonal seperti FSH, LH dan prolaktin umumnya dalam batas normal. Tidak dijumpai tumor di hipofisis. Diagnosis pada wanita ini ialah disregulasi hipotalamus-hipofisis. Sebagai penyebabnya kemungkinan besar karena gangguan pada sistem umpan balik. Kadang-kadang ditemukan kadar FSH dan prolaktin normal, namun kadar LH tinggi. Wanita ini sangat mungkin menderita sindroma ovarium polikistik. ${ }^{2}$

Penanganan wanita dengan uji $\mathrm{P}$ positif bagi wanita yang belum menginginkan anak, cukup diberikan progestogen dari hari ke 16 sampai hari ke 25 siklus haid. Hari pertama dihitung dari hari pertama terjadinya perdarahan setelah uji $\mathrm{P}$ dilakukan. Setiap habis obat pada umumnya akan terjadi perdarahan. Pengobatan diberikan untuk 3 siklus berturut-turut. Setelah itu dilihat apakah siklus haid menjadi normal kembali atau tidak. Bila masih belum terjadi siklus haid normal, maka pengobatan dilanjutkan lagi sampai dicapai siklus haid yang normal. Selama belum diperoleh siklus haid yang normal, berarti wanita tersebut terus menerus berada di bawah pengaruh estrogen yang suatu waktu dapat menyebabkan hiperplasia endometrium bahkan kanker endometrium. Pemberian progestogen pada wanita ini selain untuk mendapatkan haid yang teratur juga sekaligus untuk mencegah timbulnya kanker endometrium. Bila ternyata wanita tersebut telah mendapatkan siklus haid yang teratur, namun wanita tersebut belum menginginkan anak, maka perlu dilanjutkan penggunaan IUD, atau yang paling mudah ialah pemberian pil kontrasepsi kombinasi. Bila hasil uji $\mathrm{P}$ negatif, maka perlu dilakukan uji berikutnya dengan menggunakan estrogen dan progestogen. ${ }^{2}$

Uji dengan menggunakan estrogen dan progestogen (uji $E+P$ )

Cara melakukan uji $\mathrm{E}+\mathrm{P}$ ialah dengan memberikan estrogen, seperti etinil estradiol $50 \mu \mathrm{g}$, atau estrogen valerianat 2 $\mathrm{mg}$, atau estrogen equin konjugasi 0,625 mg selama 21 hari dan dari hari ke 12 sampai hari ke 21 diberikan progestogen 10 $\mathrm{mg} /$ hari. Paling mudah ialah dengan memberikan pil kontrasepsi kombinasi, meskipun cara ini tidak dapat dikatakan sebagai uji $\mathrm{E}+\mathrm{P}$ yang murni karena sejak awal estrogen dan progestogen diberikan bersamaan. Uji E+P dikatakan positif, bila 2 atau 3 hari setelah obat habis terjadi perdarahan. Pada wanita tertentu perdarahan dapat saja terjadi 7-10 hari setelah obat habis. Bila tidak terjadi perdarahan, maka dikatakan uji E+P negatif. ${ }^{2,3}$ Uji E+P positif artinya pada wanita ini perdarahan baru terjadi setelah diberikan estrogen. Pada wanita ini terjadi gangguan pematangan folikel, sehingga estrogen tidak dapat dihasilkan. Untuk pematangan folikel diperlukan rangsangan dari FSH dan LH, sedangkan untuk pengeluaran $\mathrm{FSH}$ dan $\mathrm{LH}$ diperlukan rangsangan dari GnRH yang dihasilkan oleh hipotalamus. Dapat dipastikan bahwa pada wanita ini tidak terjadi ovulasi.

Penanganan wanita dengan uji E+P positif yaitu penyebab folikel tidak berkembang harus dicari serta dilakukan analisis hormonal FSH, LH, dan prolaktin. Bila kadar FSH dan LH rendah, serta kadar prolaktin normal, maka diagnosisnya ialah amenorea hipogonadotropin yang disebabkan oleh insufisiensi hipotalamus-hipofisis. Bila ditemukan kadar FSH dan LH tinggi dan prolaktin normal, maka penyebab amenorea pada pasien ini ialah gangguan di ovarium, misalnya menopause prekok. Diagnosisnya ialah amenorea hipergonadotropin. Untuk memastikan secara pasti, perlu dilakukan biopsi pada ovarium. Bila FSH dan LH sangat rendah berarti tidak terjadi pematangan folikel, atau ovarium tidak memiliki folikel-folikel lagi. Untuk 
mengetahui apakah ovarium benar-benar masih mengandung folikel dan masih memiliki kemampuan untuk menumbuhkan folikel, dapat dilakukan uji stimulasi dengan hMG (uji hMG) yang dapat mengandung hormon FSH dan LH. Pada ovarium yang normal, pemberian $\mathrm{hMG}$ akan memicu pertumbuhan folikel dan memroduksi estrogen. Estrogen tersebut dapat diperiksa melalui urin atau darah. Bila didapatkan kadar estrogen yang normal, maka uji hMG dikatakan positif. Hasil uji hMG positif berarti amenorea yang terjadi disebabkan oleh rendahnya produksi FSH dan $\mathrm{LH}$ di hipofisis, atau rendahnya FSH dan LH yang bisa disebabkan oleh rendahnya produksi hormon pelepas GnRH di hipotalamus. Hasil uji hMG negatif menunjukkan bahwa ovarium tidak memiliki folikel, atau masih memiliki folikel, tetapi tidak sensitif terhadap gonadotropin seperti pada kasus sindrom ovarium resisten. ${ }^{2,3}$

Untuk mencari tahu kemungkinan lokasi gangguan yang terjadi di hipotalamus atau di hipofisis, maka perlu dilakukan uji stimulasi dengan clomifen sitrat dan uji dengan GnRH. Clomifen sitrat diberikan $100 \mathrm{mg} /$ hari selama 5-10 hari. Uji clomifen sitrat dikatakan positif bila selama penggunaan clomifen sitrat dijumpai peningkatan FSH dan $\mathrm{LH}$ serum 2 kali lipat dan 7 hari setelah penggunaan clomifen sitrat ditemukan peningkatan serum estradiol paling sedikit $200 \mathrm{pg} / \mathrm{mL}$. Darah untuk pemeriksaan FSH, LH, dan E2 diambil pada hari ke 7. Peningkatan FSH dan LH yang terjadi menunjukkan hipofisis normal, artinya masih tersedia FSH dan LH yang cukup. Bila uji clomifen sitrat negatif, berarti terjadi gangguan di hipotalamus dengan kemungkinan tidak tersedia cukup GnRH, maka tindakan selanjutnya adalah melakukan uji dengan GnRH. GnRH diberikan dengan dosis 25-100 $\mu \mathrm{g}$ intravena. Tiga puluh menit setelah pemberian $\mathrm{GnRH}$ dilakukan pengukuran kadar FSH dan LH serum. Uji GnRH dikatakan positif, bila dijumpai kadar FSH dan LH yang normal atau tinggi, hal ini berarti gangguan yang terjadi adalah di hipotalamus, sedangkan bila tidak dijumpai peningkatan FSH dan LH, maka gangguan yang terjadi ialah di hipofisis. ${ }^{2,3}$ Bila ditemukan FSH dan LH normal, namun kadar prolaktin tinggi, maka pasien ini perlu ditangani sesuai dengan piñatalaksanaan pasien dengan hiperprolaktinemia.

Pada pasien dengan uji $\mathrm{P}$ negatif dan uji $\mathrm{E}+\mathrm{P}$ positif yang belum menginginkan anak, cukup diberikan estrogen-progesteron siklik, meskipun cara ini tidak mengobati penyebab dari amenorea tersebut. Bila diduga kelainan di hipofisis, maka untuk pematangan folikel diberikan hMG atau FSH dan untuk induksi ovulasi diberikan HCG, sedangkan bila diduga kelainan tersebut di hipotalamus, maka diberikan GnRH secara pulsatif. Apabila tidak mungkin memberikan GnRH secara pulsatif, maka terpaksa diberikan FSH dari luar, terutama bagi pasien yang ingin hamil. ${ }^{2,3}$

Penanganan amenorea pada wanita dengan uji $\mathrm{P}$ dan uji $\mathrm{E}+\mathrm{P}$ negative ialah pasien diperiksa kadar FSH, LH, dan prolaktin serum. Bila hasilnya semua normal, maka diagnosis pasien ini ialah normogonadotrop amenorea. Amenorea yang terjadi disebabkan oleh adanya defek di endometrium (aplasia uterus, sindrom Asherman, dan tuberkulosis). Prognosis amenorea yang disebabkan oleh kuman TBC tergolong buruk. ${ }^{2}$

\section{Simpulan}

Amenore disebabkan disfungsi dari berbagai kompartemen yang berhubungan dengan sistem organ spesifik, yaitu: kompartemen I, gangguan pada uterus; kompartemen II, gangguan pada ovarium; kompartemen III, gangguan pada hipofisis anterior; dan kompartemen IV, gangguan pada sistem saraf pusat (hipotalamus). Mencari penyebab amenorea dapat dilakukan dengan melakukan beberapa tes atau uji. Penentuan lokasi defek anatomis spesifik bermanfaat untuk penanganan yang sesuai dengan penyebab dari amenore. $^{3}$ 
Daftar Pustaka

1. The Practice Committee of the American Society for Reproductive medicine. Current Evaluation of Amenorrhea. Fertil Steril. 2008;90(5 Suppl):S219-25

2. Baziad A. Amenorea sekunder. In Endokrinologi Ginekologi (3rd ed). Jakarta: Media Aesculapius, 2008.

3. Speroff L, Marc AF. Amenorrhea. In: Clinical Gynecologic Endocrinology \& Infertility (7th ed). Philadelphia: Lippincott Williams \& Wilkins, 2005.

4. Capella S, Morsad F, Bertrand C, Taylor S, Fernandez H. Hysteroscopic treatment of severe Asherman's syndrome and subsequent fertility. Available from: http://humrep.oxfordjournals.org/conte nt/14/5/1230.full. Cited April 2016

5. Orhue A, Aziken M, Igbefoh J. A comparison of two adjunctive treatments for intrauterine adhesions following lysis. Int J Gynaecol Obstet. 2003;82(1):49-56.

6. American Society for Reproductive Medicine. Premature Ovarian Failure (POF). [cited Apr 2016]. Available from: https://www.asrm.org.

7. Guzick D. Polycystic ovary syndrome: symptomatology, pathophysiology, and epidemiology. [cited Apr 2016]. Available from: http://www.ncbi.nlm.nih.gov/pubmed/9 855614.

8. Nestler J. Polycystic ovary syndrome: a disorder for the generalist. Fertil Steril 1998; 70: 811-12.

9. Shivaprasad C. Sheehan's syndrome: newer advances. Indian Journal of Endocrinology and Metabolism. Available from: http://www.ncbi.nlm.nih.gov/pmc/articl es/PMC3183525/. Cited April 2016

10. Shahdokht M, Babakhani L, Mohammad S, Mojtahedi K. A comparison of bromocriptine \& cabergoline on fertility outcome of hyperprolactinemic infertile women undergoing intrauterine insemination. Available from: http://www.ncbi.nlm.nih.gov/pubmed/2 0516539. Cited March 2015

11. Casanueva F, Molitch ME, Schlechte JA, Abs R, Bonert V, Bronstein MD, et al. Guidelines of the Pituitary Society for the diagnosis and management of prolactinomas. Available from: http://www.researchgate.net/publicatio n/6899790. Cited March 2015

12. National Eating Disorders Collaboration. Bulimia Nervosa. Available from: http://www.nedc.com.au/files/logos/06 38_NEDC_FS_BN_v4.pdf. Cited April 2016

13. American College of Sports Medicine. Menstrual Cycle Dysfunction. Available from: https://www.acsm.org/docs/currentcomments/menstrualcycledysfunction.p df. Cited April 2016

14. Pauli SA, Berga SL. Athletic amenorrhea: energy deficit or psychogenic challenge? Annals of the New York Academy of Sciences. 2010;1205:3338. Available from: http://www.ncbi.nlm.nih.gov/pmc/articl es/PMC2941235/. Cited April 2016

15. The Royal Australian and New Zealand College of Psychiatrists. Anorexia nervosa. Available from: https://www.ranzcp.org/Files/Resource s/Publications/CPG/Australian_Version s/aus_anorexia_nervosa-pdf.aspx. Cited April 2016

16. Lawson E, Klibanski A. Endocrine abnormalities in anorexia nervosa. [cited Apr 2016]. Available from: http://media.pituitary.org/pdf/ncpendm et0872.pdf. 